\title{
Reclassification of Desulfobacterium macestii as Desulfomicrobium macestii comb. nov.
}

Correspondence

Hans Hippe

h.h.hippe@t-online.de

\author{
Hans Hippe, ${ }^{1}$ Mikhail Vainshtein, ${ }^{2}$ G. I. Gogotova ${ }^{2}$ \\ and Erko Stackebrandt ${ }^{1,3}$
}

${ }^{1}$ DSMZ - Deutsche Sammlung von Mikroorganismen und Zellkulturen, D-38124 Braunschweig, Germany

${ }^{2}$ Institute of Biochemistry and Physiology of Microorganisms, 142292 Pushchino, Moscow Region, Russia

${ }^{3}$ Lehrstuhl für Mikrobiologie, Technische Universität Braunschweig, Germany

\begin{abstract}
Phylogenetic, chemotaxonomic and metabolic data obtained for Desulfobacterium macestii indicate that this species is not a member of the genus Desulfobacterium, but of the genus Desulfomicrobium. Phylogenetically, it is closely related to Desulfomicrobium baculatum and Desulfomicrobium norvegicum, but it can be differentiated from these species by its metabolic properties. It is therefore proposed to reclassify Desulfobacterium macestii as Desulfomicrobium macestii comb. nov.
\end{abstract}

Desulfobacterium macestii Gogotova and Vainshtein (1989) was described for a motile, Gram-negative, rod-shaped, non-spore-forming, sulfate-reducing strain from the water of a sulfide spring at Matsesta, Russia. The strain used hydrogen, formate, lactate, pyruvate and ethanol for growth and sulfate as an electron donor, and did not contain desulfoviridin. On the basis of these phenotypic properties, this strain $\left(\mathrm{M}-9^{\mathrm{T}}\right)$ was classified as a member of the genus Desulfobacterium Widdel and Bak (1992). This report presents data that are inconsistent with the current classification, but provides evidence for reclassification of strain $\mathrm{M}-9^{\mathrm{T}}\left(=\mathrm{VKM}\right.$ B $\left.-1598^{\mathrm{T}}=\mathrm{DSM} 4194^{\mathrm{T}}\right)$ as a member of the genus Desulfomicrobium.

The genus Desulfomicrobium was described by Rozanova et al. (1988, 1994) for rod-shaped, non-spore-forming, Gram-negative, sulfate-reducing bacteria that do not contain desulfoviridin and perform incomplete oxidation of organic compounds to acetate. At the time of writing, the genus includes the species Desulfomicrobium baculatum (Rozanova et al. 1988, 1994), Desulfomicrobium apsheronum (Rozanova et al., 1988, 1994), Desulfomicrobium escambiense (Sharak Genthner et al., 1994, 1996), Desulfomicrobium norvegicum (Sharak Genthner et al., 1997), Desulfomicrobium orale (Langendijk et al., 2001) and 'Desulfomicrobium hypogeium' (Krumholz et al., 1999); these have

Published online ahead of print on 14 March 2003 as DOI 10.1099/ ijs.0.02574-0.

The GenBank accession numbers for the 16S rRNA gene sequences described in this paper are: AJ237604, Desulfomicrobium macestii DSM 4194 ${ }^{\top}$; AJ277894, Desulfomicrobium baculatum DSM 4028' AJ277897, Desulfomicrobium norvegicum DSM 1741 ${ }^{\top}$; AJ237606, Desulfobacula phenolica DSM 3384 ${ }^{\mathrm{T}}$; AJ237601, Desulfobacterium anilini DSM $4660^{\top}$. been isolated from various habitats, such as the stratal water of an oil deposit, manganese ore, subsurface sandstone, forest pond, brackish water, fresh water and marine water or sediment, respectively. Phylogenetically, the genus Desulfomicrobium groups within the family Desulfovibrionaceae (Devereux et al., 1990; Tourova et al., 1998) and is phylogenetically, physiologically and chemotaxonomically distinct (e.g. in its type of oxidation of organic compounds, DNA $G+C$ content, cellular fatty acid pattern and menaquinones) from members of the genus Desulfobacterium (Collins \& Widdel, 1986; Widdel \& Bak, 1992).

Previously, Desulfobacterium macestii had been shown to grow in the absence of organic carbon sources and in the presence of sulfate with hydrogen or formate as a chemoautotroph, and with ethanol, lactate or pyruvate as a chemoorganotroph (Gogotova \& Vainshtein, 1989). These results were confirmed in the present study. In addition, it was found that Desulfobacterium macestii was able to grow on n-butanol and 1,2-propanediol and weakly on n-propanol, but failed to grow on isobutanol, 1,4-butanediol or 2,3butanediol. In contrast to previous results, fumarate and malate were used as carbon and electron sources in the presence of sulfate. In repeated experiments that used 10-15 mM organic substrate and $10 \mathrm{mM}$ sulfate, cultures grew up to an optical density of $0 \cdot 260-0 \cdot 350$ and produced 3-5 mM sulfide. In the absence of sulfate, fumarate and pyruvate were fermented, while lactate and malate were not. No growth occurred on lactate with nitrate as the electron acceptor.

Extraction of genomic DNA, PCR-mediated amplification of $16 \mathrm{~S}$ rDNA and direct sequencing of the purified PCR product were carried out according to Rainey et al. (1996). The $16 \mathrm{~S}$ rDNA sequences were aligned manually with 
published sequences obtained from GenBank/EMBL. Evolutionary distances were calculated by the method of Jukes \& Cantor (1969). Phylogenetic dendrograms were reconstructed as described by DeSoete (1983). Bootstrap analysis was used to evaluate the neighbour-joining tree topology by performing 500 resamplings (Felsenstein, 1985).

Species of the genus Desulfomicrobium form three lineages: Desulfomicrobium orale is the deepest-branching member of the genus and shows $<96 \% 16 \mathrm{~S}$ rRNA gene sequence similarity with the other species. The next-deepest-branching member is Desulfomicrobium escambiense, which shares between 98.1 and $98.3 \%$ similarity with members of the third lineage; this lineage comprises the closely related species Desulfomicrobium baculatum, Desulfomicrobium norvegicum, Desulfomicrobium apsheronum and 'Desulfomicrobium hypogeium' (99-4-99.8\% similarity). This cluster also contains Desulfobacterium macestii DSM $4194^{\mathrm{T}}$, which shares $100 \% 16 \mathrm{~S}$ rRNA gene similarity with Desulfomicrobium norvegicum DSM $1741^{\mathrm{T}}, 99 \cdot 8 \%$ similarity with Desulfomicrobium baculatum DSM $4028^{\mathrm{T}}$ and 'Desulfomicrobium hypogeium' $\mathrm{CN}-\mathrm{A}^{\mathrm{T}}$ and 99.6\% similarity with Desulfomicrobium apsheronum DSM $5918^{\mathrm{T}}$. The published sequence of Desulfomicrobium baculatum VKM B-1378 (GenBank no. AF030438) differs from the newly analysed sequence of Desulfomicrobium baculatum DSM $4028^{\mathrm{T}}$ (GenBank no. AJ277894) by $1 \cdot 3 \%$. This in the sequence explains the different phylogenetic positions of Desulfomicrobium baculatum, which branches with Desulfomicrobium apsheronum in the study of Langendijk et al. (2001) and with Desulfomicrobium norvegicum and Desulfobacterium macestii in the present study (Fig. 1).

For analysis of cellular fatty acids, Desulfobacterium macestii DSM $4194^{\mathrm{T}}$ was grown in a pyruvate- and malate-containing medium with sulfate and thiosulfate as electron acceptors at $35^{\circ} \mathrm{C}$, as described by Vainshtein et al. (1992). Cells were harvested at the end of the exponentialgrowth phase and washed twice with $1 \%(\mathrm{w} / \mathrm{v}) \mathrm{NaCl}$. Saponification, methylation of fatty acids, extraction, separation by GC and analysis of the fatty acid methyl esters were done as described previously (Vainshtein et al., 1992; Meier et al., 1993), by using the MIDI system (Microbial ID). The overall fatty acid composition of Desulfobacterium macestii was very similar to those of species of the genus Desulfomicrobium (Vainshtein et al., 1992; Langendijk et al., 2001) but distinct from those of representatives of the genera Desulfovibrio and Desulfobacterium (Taylor \& Parkes, 1983; Dowling et al., 1986; Vainshtein et al., 1992). The predominant fatty acids in Desulfobacterium macestii were the branched-chained, odd-numbered fatty acids iso $\mathrm{C}_{15: 0}(13.6 \%)$, iso $\mathrm{C}_{17: 0}(10 \cdot 1 \%)$ and iso $\mathrm{C}_{17: 1} \omega 10 c$ $(32 \cdot 9 \%)$, as well as significant amounts of the unbranched, even-numbered fatty acids $\mathrm{C}_{16: 0}(4 \cdot 2 \%), \mathrm{C}_{18: 0}(5 \cdot 5 \%)$ and $\mathrm{C}_{18: 1} \omega 7 c(6 \cdot 3 \%)$. In particular, iso $\mathrm{C}_{17: 1} \omega 10 c$ has been regarded as a marker for members of the Desulfovibrionaceae (Edlund et al., 1985; Taylor \& Parkes, 1985; Tourova et al., 1998). 10-Methyl fatty acids, claimed to be characteristic of the genera Desulfobacter and Desulfobacterium

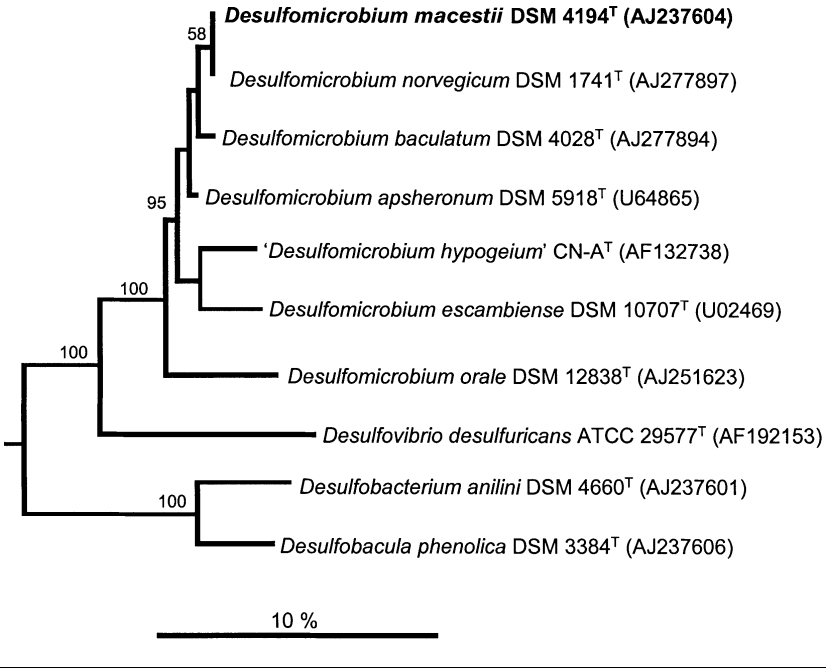

Fig. 1. Dendrogram of $16 \mathrm{~S}$ rRNA gene sequences (DeSoete, 1983), displaying the phylogenetic position of Desulfomicrobium macestii DSM $4194^{\top}$. Numbers at branching points refer to bootstrap values (1000 resamplings). The tree was rooted with the 16S rRNA gene sequences of Myxobacteria and Bdellovibrio species. Bar, 10 nucleotide substitutions per 100 sequence positions.

(Dowling et al.,1986; Vainshtein et al., 1992), were absent from Desulfobacterium macestii, as well as from members of the genera Desulfomicrobium and Desulfovibrio. Desulfobacterium macestii differs only slightly from the phylogenetically closely related type strains of Desulfomicrobium norvegicum and Desulfomicrobium baculatum in quantitative, but not qualitative, fatty acid composition.

Cells for isoprenoid quinone analysis (Kroppenstedt, 1985; Hippe et al., 1997) were grown in the medium described above, modified to contain $10 \mathrm{~g} \mathrm{NaCl}^{-1}$ and $2 \cdot 2 \mathrm{~g} \mathrm{Na}$ lactate $1^{-1}$ to replace pyruvate and malate. The principal isoprenoid quinone in Desulfobacterium macestii was menaquinone with six isoprenoid units (MK-6). This is not in accordance with the menaquinone composition of Desulfobacterium species, which contain either MK-7 or MK-7 $\left(\mathrm{H}_{2}\right)$ as the major menaquinone (Collins \& Widdel, 1986; Widdel \& Bak, 1992). MK-6 is typically found in members of the family Desulfovibrionaceae and has also been detected in Desulfomicrobium norvegicum (formerly Desulfovibrio desulfuricans Norway 4) (Collins \& Widdel, 1986).

Genomic similarities between the closely related species Desulfomicrobium norvegicum DSM $1741^{\mathrm{T}}$ and Desulfobacterium macestii DSM $4194^{\mathrm{T}}$ were analysed by DNA-DNA reassociation, following the renaturation method (Escara \& Hutton, 1980; Huß et al., 1983; Jahnke, 1992) in $1 \times$ SSC (saline/sodium citrate) buffer plus $10 \%$ DMSO at $65{ }^{\circ} \mathrm{C}$. The mean binary reassociation value of triple determination was $71 \cdot 7 \%$ (range, $69 \cdot 7-73 \cdot 5 \%$ ), which is close to the recommended threshold value for 
species delineation (70\%; Wayne et al., 1987). The reassociation value for Desulfomicrobium baculatum DSM $4028^{\mathrm{T}}$ and Desulfomicrobium norvegicum ATCC $27774^{\mathrm{T}}$ is only $27 \cdot 4 \%$ (Sharak Genthner et al., 1997), indicating that strain DSM $4028^{\mathrm{T}}$ and Desulfobacterium macestii DSM $4194^{\mathrm{T}}$ also share significantly less than $70 \%$ similarity.

Results of phylogenetic and chemotaxonomic studies clearly identify Desulfobacterium macestii as a member of the genus Desulfomicrobium within the family Desulfovibrionaceae. DNA-DNA hybridization points toward a close relationship with Desulfomicrobium norvegicum, but Desulfobacterium macestii DSM $4194^{\mathrm{T}}$ differs from the type strain of Desulfomicrobium norvegicum, as well as from Desulfomicrobium baculatum, by chemoautotrophic growth on $\mathrm{H}_{2}$ plus $\mathrm{CO}_{2}$, lack of growth on malate in the absence of sulfate, and sulfate reduction during growth on fumarate and malate in the presence of sulfate. We therefore propose to reclassify Desulfobacterium macestii Gogotova and Vainshtein (1989) as Desulfomicrobium macestii comb. nov.

\section{Description of Desulfomicrobium macestii comb. nov.}

Desulfomicrobium macestii (ma. ces'ti.i. L. neut. adj. macestii referring to the town Matsesta at Sotschi, Black Sea, Russia, from where the type strain was isolated).

The description is based on the data of Gogotova \& Vainshtein (1989) and data from recent studies.

Cells are straight rods, $0 \cdot 7 \times 1 \cdot 9-2 \cdot 0 \mu \mathrm{m}$ in size and motile by a single polar flagellum. Spores are not formed. Gramnegative. Strictly anaerobic chemo-organotroph or chemoautotroph. $\mathrm{H}_{2}$, formate, pyruvate, lactate, ethanol, propanol, butanol, 1,2-propanediol, fumarate and malate are used as electron donors. Incomplete oxidation. Acetate, butyrate, methanol, isobutanol, 1,4-butanediol, 2,3-butanediol, choline, glucose and sucrose are not utilized. Sulfate, sulfite and thiosulfate serve as electron acceptors and are reduced to $\mathrm{H}_{2} \mathrm{~S}$. Fermentative growth occurs on pyruvate and fumarate in the absence of sulfate. Optimum temperature for growth is $35^{\circ} \mathrm{C}$, range is $15-40{ }^{\circ} \mathrm{C}$; optimum $\mathrm{pH}$ for growth is $7 \cdot 2$, range is $6 \cdot 5-8 \cdot 0$. Optimum growth occurs in $1 \cdot 3 \% \mathrm{NaCl}$, range $0-2 \cdot 5 \%$. Major fatty acids are branchedchain and odd-numbered: iso $\mathrm{C}_{15: 0}$, iso $\mathrm{C}_{17: 0}$ and iso $\mathrm{C}_{17: 1} \omega 10 c$. Principal menaquinone is MK-6. Cells contain $b$ - and $c$-type cytochromes and an active hydrogenase. Desulfoviridin is not present. DNA base ratio is $58.0 \mathrm{~mol} \%$ $\mathrm{G}+\mathrm{C}$ (by thermal denaturation).

The type strain is $\mathrm{M}-9^{\mathrm{T}}\left(=\mathrm{VKM} B-1598^{\mathrm{T}}=\mathrm{DSM} 4194^{\mathrm{T}}\right)$. Isolated from a sulfide spring at Matsesta, Russia.

\section{Acknowledgements}

We thank Gabriele Pötter for her assistance in fatty acids and menaquinone analyses.

\section{References}

Collins, M. D. \& Widdel, F. (1986). Respiratory quinones of sulphatereducing and sulphur-reducing bacteria: a systematic investigation. Syst Appl Microbiol 8, 8-18.

DeSoete, G. (1983). A least squares algorithm for fitting additive trees to proximity data. Psychometrika 48, 621-626.

Devereux, R., He, S.-H., Doyle, C. L., Orkland, S., Stahl, D. A., LeGall, J. \& Whitman, W. B. (1990). Diversity and origin of Desulfovibrio species: phylogenetic definition of a family. J Bacteriol 172, 3609-3619.

Dowling. N. J. E., Widdel, F. \& White, D. C. (1986). Phospholipid ester-linked fatty acid biomarkers of acetate-oxidizing sulphatereducers and other sulphide-forming bacteria. J Gen Microbiol 132, 1815-1825.

Edlund, A., Nichols, P. D., Roffey, R. \& White, D. C. (1985). Extractable and lipopolysaccharide fatty acid and hydroxy acid profiles from Desulfovibrio species. J Lipid Res 26, 982-988.

Escara, J. F. \& Hutton, J. R. (1980). Thermal stability and renaturation of DNA in dimethyl sulfoxide solutions: acceleration of the renaturation rate. Biopolymers 19, 1315-1327.

Felsenstein, J. (1985). Confidence limits on phylogenies: an approach using the bootstrap. Evolution 39, 783-791.

Gogotova, G. I. \& Vainshtein, M. B. (1989). Description of a sulfatereducing bacterium, Desulfobacterium macestii sp. nov., which is capable of autotrophic growth. Microbiology (English translation of Mikrobiologiya) 58, 64-68.

Hippe, H., Hagenauer, H. \& Kroppenstedt, R. M. (1997). Menadione requirement for sulfate-reduction in Desulfotomaculum aeronauticum, and emended species description. Syst Appl Microbiol 20, 554-558.

Huß, V. A. R., Festl, H. \& Schleifer, K.-H. (1983). Studies on the spectrophotometric determination of DNA hybridization from renaturation rates. Syst Appl Microbiol 4, 184-192.

Jahnke, K.-D. (1992). Basic computer program for evaluation of spectroscopic DNA renaturation data from Gilford System 2600 spectrophotometer on a PC/XT/AT type personal computer. J Microbiol Methods 15, 61-73.

Jukes, T. H. \& Cantor, C. R. (1969). Evolution of protein molecules. In Mammalian Protein Metabolism, pp. 21-132. Edited by H. N. Munro. New York: Academic Press.

Kroppenstedt, R. M. (1985). Fatty acid and menaquinone analysis of actinomycetes and related organisms. In Chemical Methods in Bacterial Systematics (Society for Applied Bacteriology Technical Series no. 20), pp. 173-199. Edited by M. Goodfellow \& D. E. Minnikin. New York: Academic Press.

Krumholz, L. R., Harris, S. H., Tay, S. T. \& Suflita, J. M. (1999). Characterization of two subsurface $\mathrm{H}_{2}$-utilizing bacteria, Desulfomicrobium hypogeium sp. nov. and Acetobacterium psammolithicum sp. nov., and their ecological roles. Appl Environ Microbiol 65, 2300-2306.

Langendijk, P. S., Kulik, E. M., Sandmeier, H., Meyer, J. \& van der Hoeven, J. S. (2001). Isolation of Desulfomicrobium orale sp. nov. and Desulfovibrio strain NY682, oral sulfate-reducing bacteria involved in human periodontal disease. Int J Syst Evol Microbiol 51, 1035-1044.

Meier, A., Kirschner, P., Schröder, K.-H., Wolters, J., Kroppenstedt, R. M. \& Böttger, E. C. (1993). Mycobacterium intermedium sp. nov. Int J Syst Bacteriol 43, 204-209.

Rainey, F. A., Ward-Rainey, N., Kroppenstedt, R. M. \& Stackebrandt, E. (1996). The genus Nocardiopsis represents a phylogenetically coherent taxon and a distinct actinomycete lineage: proposal of Nocardiopsaceae fam. nov. Int J Syst Bacteriol 46, 1088-1092. 
Rozanova, E. P., Nazina, T. N. \& Galushko, A. S. (1988). Isolation of a new genus of sulfate-reducing bacteria and description of a new species of this genus, Desulfomicrobium apsheronum gen. nov., sp. nov. Microbiology (English translation of Mikrobiologiya) 57, 514-520.

Rozanova, E. P., Nazina, T. N. \& Galushko, A. S. (1994). Desulfomicrobium apsheronum gen. nov., sp. nov. In Validation of the Publication of New Names and New Combinations Previously Effectively Published Outside the IJSB, List no. 49. Int J Syst Bacteriol 44, 370-371.

Sharak Genthner, B. R., Mundfrom, G. \& Devereux, R. (1994). Characterization of Desulfomicrobium escambium sp. nov. and proposal to assign Desulfovibrio desulfuricans Norway 4 to the genus Desulfomicrobium. Arch Microbiol 161, 215-219.

Sharak Genthner, B. R., Mundfrom, G. \& Devereux, R. (1996). Desulfomicrobium escambiense sp. nov. In Validation of the Publication of New Names and New Combinations Previously Effectively Published Outside the IJSB, List no. 59. Int J Syst Bacteriol 46, 1189-1190.

Sharak Genthner, B. R., Friedman, S. D. \& Devereux, R. (1997). Reclassification of Desulfovibrio desulfuricans Norway 4 as Desulfomicrobium norvegicum comb. nov. and confirmation of Desulfomicrobium escambiense (corrig., formerly "escambium") as a new species in the genus Desulfomicrobium. Int J Syst Bacteriol 47, 889-892.
Taylor, J. \& Parkes, R. J. (1983). The cellular fatty acids of the sulphate-reducing bacteria, Desulfobacter sp., Desulfobulbus sp. and Desulfovibrio desulfuricans. J Gen Microbiol 129, 3303-3309.

Taylor, J. \& Parkes, R. J. (1985). Identifying different populations of sulphate-reducing bacteria within marine sediment systems, using fatty acid biomarkers. J Gen Microbiol 131, 631-642.

Tourova, T. P., Nazina, T. N., Poltaraus, A. B. \& Osipov, G. A. (1998). Phylogenetic position and chemotaxonomic characteristics of sulfatereducing bacteria of the genus Desulfomicrobium. Microbiology (English translation of Mikrobiologiya) 67, 663-669.

Vainshtein, M. B., Hippe, H. \& Kroppenstedt, R. M. (1992). Cellular fatty acid composition of Desulfovibrio species and its use in classification of sulfate-reducing bacteria. Syst Appl Microbiol 15, 554-566.

Wayne, L. G., Brenner, D. J., Colwell, R. R. \& 9 other authors (1987). International Committee on Systematic Bacteriology. Report of the ad hoc committee on reconciliation of approaches to bacterial systematics. Int J Syst Bacteriol 37, 463-464.

Widdel, F. \& Bak, F. (1992). Gram-negative mesophilic sulfatereducing bacteria. In The Prokaryotes, 2nd edn, vol. 4, pp. 3352-3378. Edited by A. Balows, H. G. Trüper, M. Dworkin, W. Harder \& K.-H. Schleifer. New York: Springer. 